\title{
活性ガス中蒸発法による化合物微粒子
}

\section{束エ大・エ 小山直樹長含策磨}

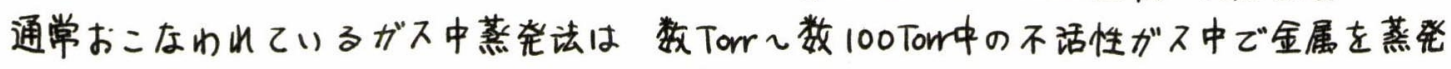

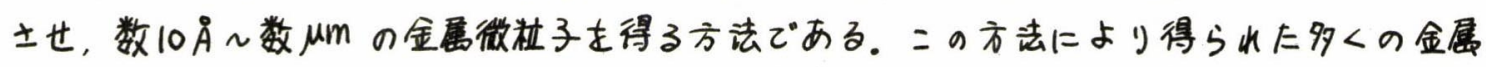
微粒子の秸晶構造および晶磨について詳しく研究がな士れている。本研究では不活性ガスの かわりに活性ガスを用いて化后物微粒子を作製し，その桠造を明らかたすることを目的とし E.

微粒子作製の装置は真空蒸着装置を用いた。まず10 Tor $\mathrm{NH}_{3}$ ガスを䄪100 Tor 尊入し、W楾フィラメントから金属を蒸発士せた。蒸登士世金属は

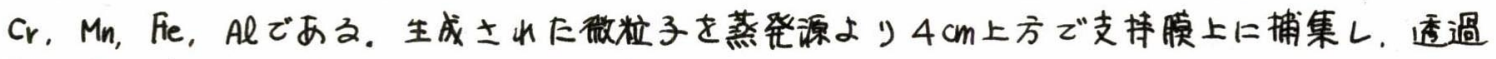
電子影微鏡および電子回折を用いて钲察した。

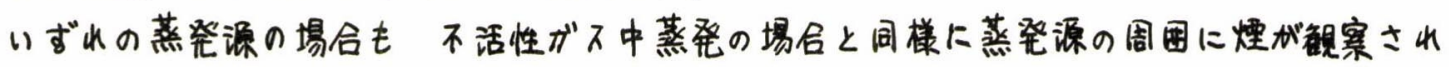

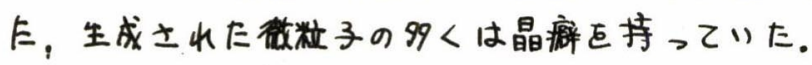

$\mathrm{C}_{\mathrm{r}}$ 一N $\mathrm{NH}_{3}$ : 生成士れた微粒子は $\mathrm{CrN}(\mathrm{NaCl}$ 型)であり，明確な晶癖を示すものの大部分は立

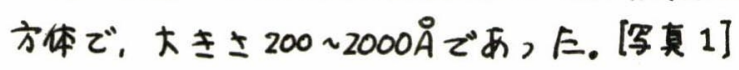

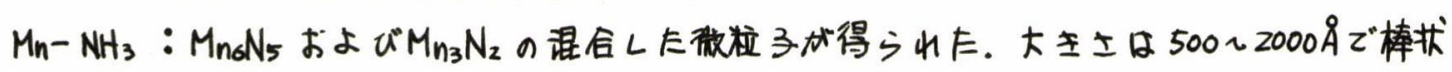
および名面体をなす粒子かららっていた。

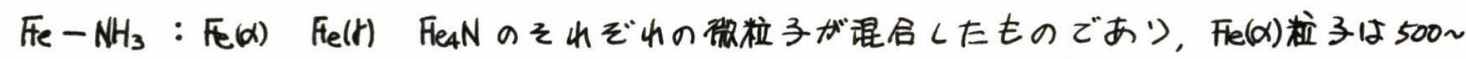

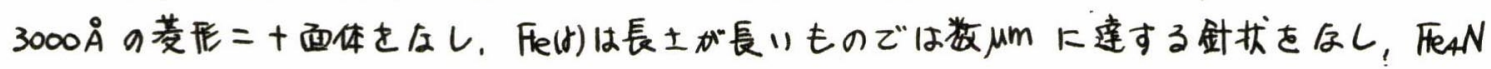

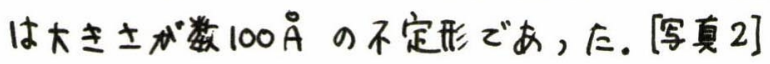

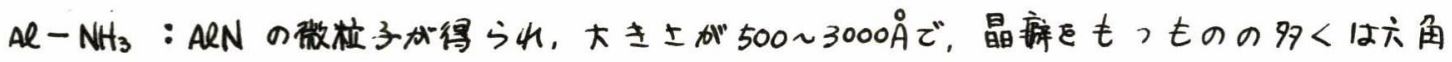
链および六角柱をはす粒子であり。また複数の結晶がらる複雑は形と与之るものもあった。

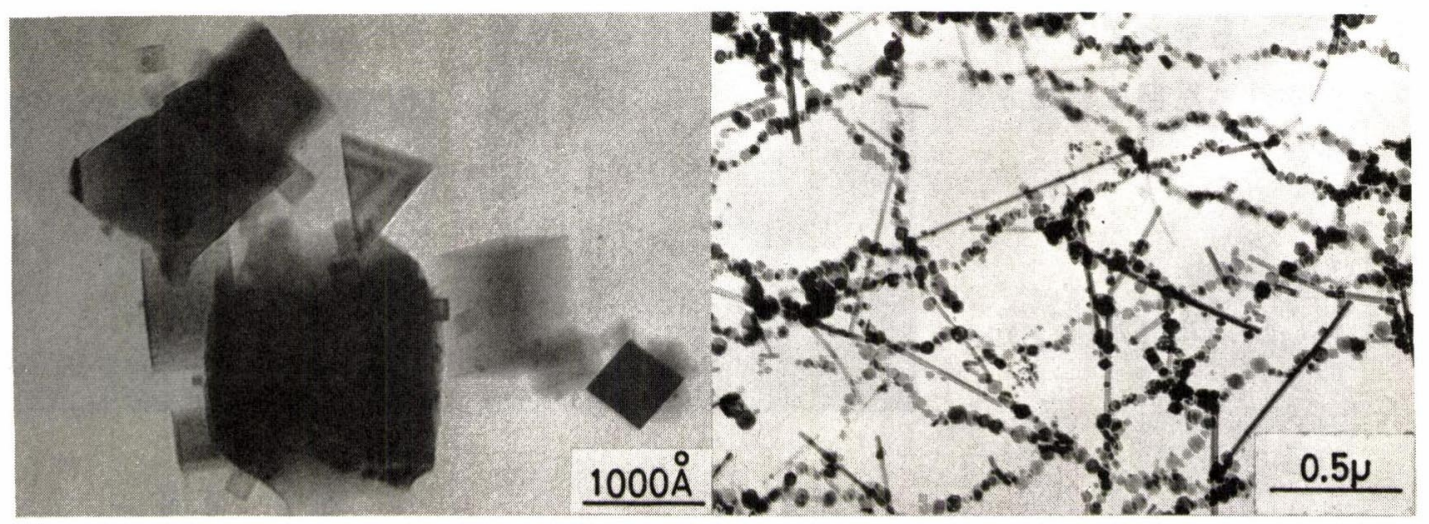

写真 $1 \mathrm{CrN}$ 微柆子 $\left(\mathrm{NH}_{3}\right.$ 100 Torr $)$

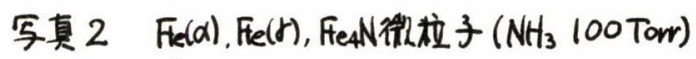

